\title{
Ground improvement of soft soil by geotextile-encased \\ columns
}

1 Iman Hosseinpour PhD

Postdoctoral Researcher, Graduate School of Engineering (COPPE), Federal University of Rio de Janeiro (UFRJ), Rio de Janeiro, RJ, Brazil (corresponding author: i.hosseinpour@gmail.com)

2 Marcio S. S. Almeida PhD, MICE

Full Professor, Graduate School of Engineering (COPPE), Federal University of Rio de Janeiro (UFRJ), Rio de Janeiro, RJ, Brazil
3 Mario Riccio PhD

Associate Professor, Faculty of Engineering, Federal University of Juiz de Fora (UFJF), Juiz de Fora, MG, Brazil
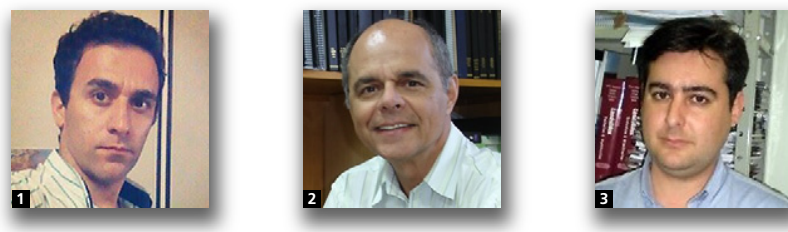

This paper compares the field response of two test embankments constructed on similar soft soil deposits. The un-strengthened foundation had vertical drains underneath the embankment and the strengthened foundation had geotextile-encased granular columns, both provided with basal geogrid reinforcement. The effectiveness of the encased granular columns was assessed by comparing the settlement below the embankments, the horizontal displacement of the soft foundation and the excess pore pressures in the middle of the soft clay layer. The results showed that the granular encased columns significantly reduced the maximum settlement occurring below the embankment as well as the maximum horizontal displacement in the clayey foundation. At the same settlement level, the load-carrying capacity of the strengthened foundation was found to increase by as much as around 2.5 times that of the un-strengthened one. It was also observed that the geotextile-encased granular columns caused a noticeable reduction in the maximum excess pore pressure following load application. Furthermore, the degree of consolidation achieved at the end of embankment construction was quite high when encased granular columns were used.

\section{Notation}

$a, b$

$C_{\mathrm{c}}$

$c_{\mathrm{h}}$

$c_{\mathrm{V}}$

$d_{\mathrm{c}}$

$d_{\mathrm{e}}$

$d_{\mathrm{w}}$

$e$

$e_{0}$

$F_{\mathrm{s}}$

$J$

$L_{\mathrm{c}}$ rectangular dimensions of vertical drain (m) compression index (dimensionless) coefficient of horizontal consolidation $\left(\mathrm{m}^{2} / \mathrm{s}\right)$ coefficient of vertical consolidation $\left(\mathrm{m}^{2} / \mathrm{s}\right)$ diameter of granular column (m) diameter of influence area $(\mathrm{m})$ equivalent diameter of vertical drain (m) void ratio (dimensionless) initial void ratio factor of safety (dimensionless) geosynthetic tensile stiffness $(\mathrm{kN} / \mathrm{m})$ length of granular column (m) total applied load $(\mathrm{kPa})$ centre-to-centre spacing between granular columns or vertical drains $(\mathrm{m})$ sensitivity degree (dimensionless) undrained shear strength $(\mathrm{kPa})$ time factor for horizontal drainage (dimensionless) time (d)

degree of radial consolidation (dimensionless) natural water content $(\%)$ plasticity index $(\%)$ depth $(\mathrm{m})$ submerged unit weight $\left(\mathrm{kN} / \mathrm{m}^{3}\right)$ excess pore water pressure $(\mathrm{kPa})$ soil horizontal displacement (m) maximum soil horizontal displacement $(\mathrm{m})$ settlement $(\mathrm{m})$ maximum settlement $(\mathrm{m})$

\section{Introduction}

The construction of embankments on soft soils requires careful control of stability and settlement (Bergado et al., 1994; Rowe and Leroueil, 2001). Embankments may be economically built on soft soil simply by using reinforcement to improve their stability (Chai et al., 2002; Rowe et al., 1995) and vertical 
drains to accelerate the settlement (Almeida et al., 2010, 2011; Holtz, 1987; Indraratna et al., 1992). Magnani et al. (2010) compared the behaviour of three test embankments with different arrangements of geosynthetic reinforcement and vertical drains. It was observed that the reinforcement significantly increased the factor of safety and reduced the settlement, while the vertical drains accelerated the latter.

Granular columns can be an alternative to improve the loadcarrying capacity, reduce settlement and enhance the stability of an embankment on soft soil (Greenwood, 1970; Mitchell and Huber, 1985). Encasing the granular columns with geosynthetic material has been shown to reduce column bulging and overall displacements of the soft ground while the loadcarrying capacity becomes greater than that of ordinary granular columns (Ali et al., 2012; Almeida et al., 2013; Black et al., 2007; Castro and Sagaseta, 2013; Gniel and Bouazza, 2010; Hosseinpour et al., 2014; Murugesan and Rajagopal, 2006; Raithel and Kempfert, 2000). The geosynthetic encasement also prevents the lateral squeezing of the clay particles into the stone aggregates, leading to minimal loss of stone material and maintaining the drainage capacity of the granular columns (Almeida et al., 2015; Hosseinpour et al., 2015).

This paper compares the field performance of two reinforced test embankments by analysing instrumentation results. The test embankments were constructed on very similar soft deposits - one over a soft clay foundation strengthened with geotextile-encased granular columns and the other over an un-strengthened soft clay foundation. The influence of the geotextile-encased granular columns is discussed by comparing the settlements measured below the embankment centreline, the horizontal displacement of the soil underneath the embankment toes, the ratio between the maximum horizontal and vertical deformations and the excess pore water pressures in the middle of the soft clay layers.

\section{Field load tests}

The monitoring data available for a reinforced embankment called TE1 (Magnani et al., 2009, 2010) are compared with the instrumentation results obtained from a test embankment built over geotextile-encased granular columns called TE2. The geometrical and geotechnical properties of the test embankments and their supporting foundations are now described.

\subsection{Un-strengthened soft foundation (TE1)}

In 2002, a $4 \cdot 0 \mathrm{~m}$ high test embankment (TE1) was constructed over $8.0 \mathrm{~m}$ thick soft clay located in Florianopolis, Brazil (Magnani et al., 2010). The embankment was provided with a basal reinforcement (tensile stiffness $J=1700 \mathrm{kN} / \mathrm{m}$ ) and the soft clay with prefabricated vertical drains (PVDs). The vertical drains, named Colbon-drain CX 1000, had rectangular dimensions of $10 \mathrm{~cm} \times 0.5 \mathrm{~cm}$ and were installed in a $1.3 \mathrm{~m}$ centre-to-centre spacing in a triangular array. The soft clay underlying the top sand layer was normally consolidated clay due to a $1.8 \mathrm{~m}$ thick hydraulic fill working platform placed 6 years prior to the construction of the test embankment.

The undrained strength $\left(S_{\mathrm{u}}\right)$ in the middle of the soft clay profile was approximately equal to $16 \mathrm{kPa}$. The test embankment, with slopes inclined at $1 \mathrm{~V}: 1 \cdot 5 \mathrm{H}$, was built in almost undrained conditions in around $60 \mathrm{~d}$ and then taken to the failure site. The vertical drains had a minor role regarding the acceleration of settlements, as confirmed by another test embankment built at the side of TE1, also reinforced but without drains. The maximum embankment total vertical stress was about $60 \mathrm{kPa}$ applied in ten small loading stages. The test embankment was instrumented for vertical displacement (settlement plates), horizontal deformation beneath the embankment toes (vertical inclinometers), excess pore pressure (piezometers) and tensile force at basal reinforcement (load cells), which is not, however, analysed in this paper. Magnani et al. $(2009,2010)$ discussed in detail the performance of test embankment TE1, whose main geometric and instrumentation details of interest here are presented in Figure 1(a).

\subsection{Strengthened soft foundation (TE2)}

A $5.3 \mathrm{~m}$ high test embankment (TE2) with total applied vertical stress of around $150 \mathrm{kPa}$ was built over around $8.0 \mathrm{~m}$ thick soft clay in Rio de Janeiro, Brazil. The soft deposit was lightly over-consolidated and covered by an about $1.8 \mathrm{~m}$ thick sand working platform on top. Thirty-six geotextile-encased granular columns, arranged in a square mesh, stabilised the test area. The encased granular columns were implemented using the displacement method with an average centre-tocentre spacing $(S)$ equal to $2 \cdot 0 \mathrm{~m}$. The material used to form the granular column was crushed stone aggregate with particle sizes varying between 10 and $35 \mathrm{~mm}$ and angle of friction equal to $40^{\circ}$. The granular columns were $0.8 \mathrm{~m}$ in diameter $\left(d_{\mathrm{c}}\right), 11 \mathrm{~m}$ long $\left(L_{\mathrm{c}}\right)$ and encased by a seamless woven geotextile with a tensile stiffness of $J=1750 \mathrm{kN} / \mathrm{m}$.

The embankment construction was performed in four loading stages, including consolidation intervals, over $65 \mathrm{~d}$, followed by a 6 month consolidation period after embankment completion. Unlike the previous case taken to the failure site, this field load test was performed to investigate the in-service behaviour of the strengthened soft clay. The general performance of the soft foundation was monitored with respect to the settlement below the embankment centreline (settlement sensors), soil horizontal displacement beneath the embankment toes (vertical inclinometers), excess pore pressures in soft clay (piezometers), total vertical stresses below the embankment (total stress cells) and hoop strain in the geotextile encasement (extensometers); however, these last two measurements are not discussed as they are out of the scope of this study. The main geometric and instrumentation details of TE2 are illustrated in Figure 1(b). 


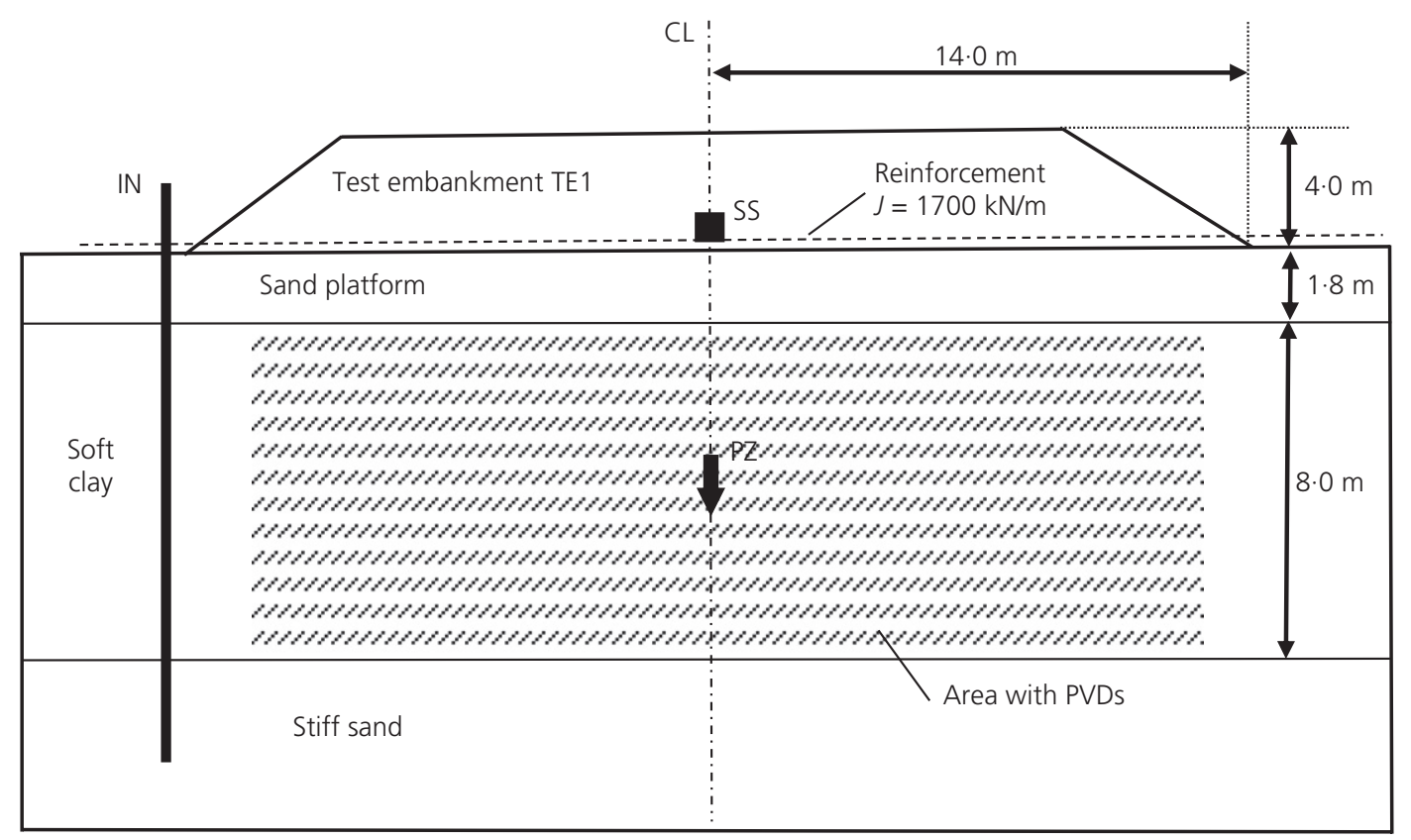

(a)

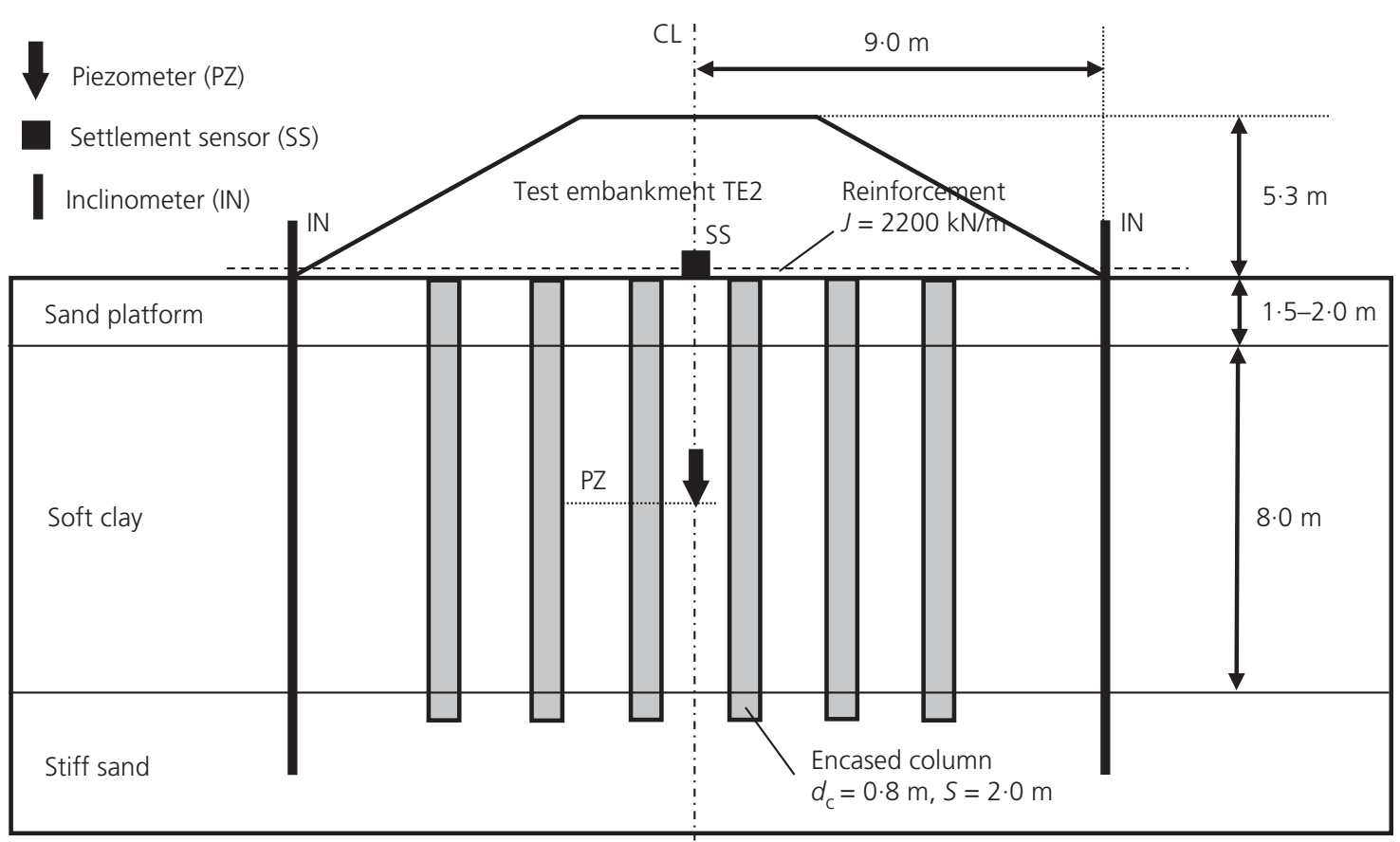

(b)

Figure 1. Embankment geometry and instrumentation:

(a) un-strengthened foundation; (b) strengthened foundation

The geometrical characteristics and geotechnical properties of the two soft clay foundations were quite similar in terms of clay thickness, around $8.0 \mathrm{~m}$, overlain by a $1.5-1.8 \mathrm{~m}$ thick working platform with the water level located $1.2-1.5 \mathrm{~m}$ below the ground surface. Table 1 summarises the main features of the two test embankments.

\subsection{Soft clay properties}

The geotechnical properties of the two soft clay foundations were also similar for undrained strength, coefficient of consolidation and saturated unit weight, thus allowing a comparison of the performance of un-strengthened (TE1) and strengthened foundations (TE2). 


Clay thickness: $\mathrm{m}$
Thickness of working platform: $\mathrm{m}$
Ground treatment technique
Modulus of basal reinforcement: $\mathrm{kN} / \mathrm{m}$
Maximum embankment height: $\mathrm{m}$
Maximum applied load: $\mathrm{kPa}$
Construction period: $\mathrm{d}$
Final factor of safety

8.0

$1 \cdot 80$

Vertical drains

1700

4.0

60

60

$1 \cdot 0$
$7 \cdot 0-8 \cdot 0$

$1 \cdot 50-2 \cdot 0$

Encased granular columns 2000

$5 \cdot 35$

150

65

$1 \cdot 8^{\mathrm{a}}$

${ }^{a}$ Obtained by plane strain analysis (Hosseinpour, 2015)

Table 1. Main features of the two test embankments: TE1, un-strengthened foundation; TE2, strengthened foundation

Profiles of the undrained shear strength $\left(S_{\mathrm{u}}\right)$ were obtained by means of piezocone tests with average values equal to 16 and $18 \mathrm{kPa}$ for TE1 and TE2, respectively (Figure 2(a)). The values of the compressibility ratio $\left(\mathrm{CR}=C_{\mathrm{c}} /\left(1+e_{0}\right)\right)$ of the two clay foundations obtained from the data of oedometer consolidation tests are also plotted in Figure 2(b), illustrating an average value of 0.35 in the middle of the soft clay for both test embankments. The main geotechnical properties of the soft clay foundations supporting the test embankments are also shown in Table 2.

\section{Results and discussion}

The influence of the geotextile-encased granular columns is discussed by analysing the data provided by ground

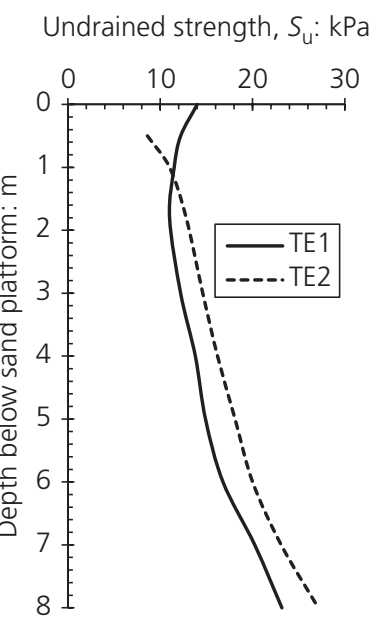

(a)

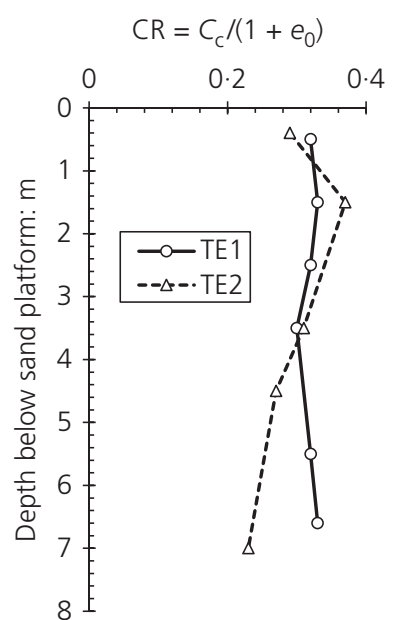

(b)
Figure 2. Geotechnical properties of the soft foundations beneath TE1 and TE2: (a) profiles of undrained strength (piezocone tests); (b) values of compression ratio (oedometer tests) instrumentation for the two test embankments. The main variables analysed in the following sections are the settlement below the embankments, the maximum soil horizontal displacements, the ratio between maximum settlements and horizontal displacements and the excess pore pressures measured in the middle of the soft clay layer.

\subsection{Settlement below the embankment}

Figure 3 shows the settlement below the embankment centreline $\left(\delta_{\mathrm{v}}\right)$ (top of the working platform) plotted against the corresponding embankment applied load $(q)$ for both TE1 and TE2. The time variation of the settlement was not considered for the comparison as the main objective was to assess the influence of the encased columns on the load-carrying response of the stabilised soft ground. Figure 3 shows that, for both test embankments, the settlement increased sharply once load application was performed (i.e. embankment height increased). However, that increase was much more noticeable for TE2 since a higher vertical stress was applied.

A direct comparison between TE1 and TE2 indicates that the geotextile-encased granular columns caused the settlement below the embankment to reduce substantially. For instance, at a total applied load equal to $60 \mathrm{kPa}$ the measured settlement for TE1 was $500 \mathrm{~mm}$, while the use of the encased granular columns caused the settlement to reduce to about $100 \mathrm{~mm}$, resulting in a virtual settlement improvement factor of around 5. It was also observed that soil stabilisation using geotextileencased granular columns significantly improved the loadcarrying capacity of the soft clay foundation. As seen in Figure 3 , when the settlement was $300 \mathrm{~mm}$, the un-strengthened foundation (TE1) supported a total load of about $q=50 \mathrm{kPa}$, but at the same settlement level the geotextile-encased columns (TE2) caused the load-carrying capacity to increase noticeably, by as much as 2.4 times that of TE1. This provides a significant example of the ground improvement benefits of using granular encased columns in soft clay foundations. 
Natural water content, $w_{\mathrm{n}}: \%$

Plasticity index, $w_{\mathrm{p}}$ : \%

Submerged unit weight, $\gamma^{\prime}: \mathrm{kN} / \mathrm{m}^{3}$

Void ratio, e

Compression ratio (CR)

Coefficient of vertical consolidation, $c_{\mathrm{v}}: \mathrm{m}^{2} / \mathrm{s}$

Coefficient of horizontal consolidation, $c_{h}: \mathrm{m}^{2} / \mathrm{s}$

Clay sensitivity, $S_{t}$

Undrained strength, $S_{\mathrm{u}}: \mathrm{kPa}$

Over-consolidation ratio (OCR)

$100-170$
80
$3 \cdot 4-4 \cdot 2$
$2 \cdot 9-4 \cdot 4$
$0 \cdot 30-0 \cdot 45$
$0 \cdot 7-1 \cdot 0 \times 10^{-8}$
$2 \cdot 1 \times 10^{-8}$
$3-6$
$10-20$
$1 \cdot 0$

$90-120$

$80-140$

$3 \cdot 8-4 \cdot 5$

$2 \cdot 4-3 \cdot 1$

$0 \cdot 30$

$2 \cdot 3 \times 10^{-8}$

$3.7 \times 10^{-8}$

5

$15-20$

$1 \cdot 3-1 \cdot 0$

Table 2. Geotechnical properties of the soft clay foundations for TE1 (un-strengthened foundation) and TE2 (strengthened foundation)

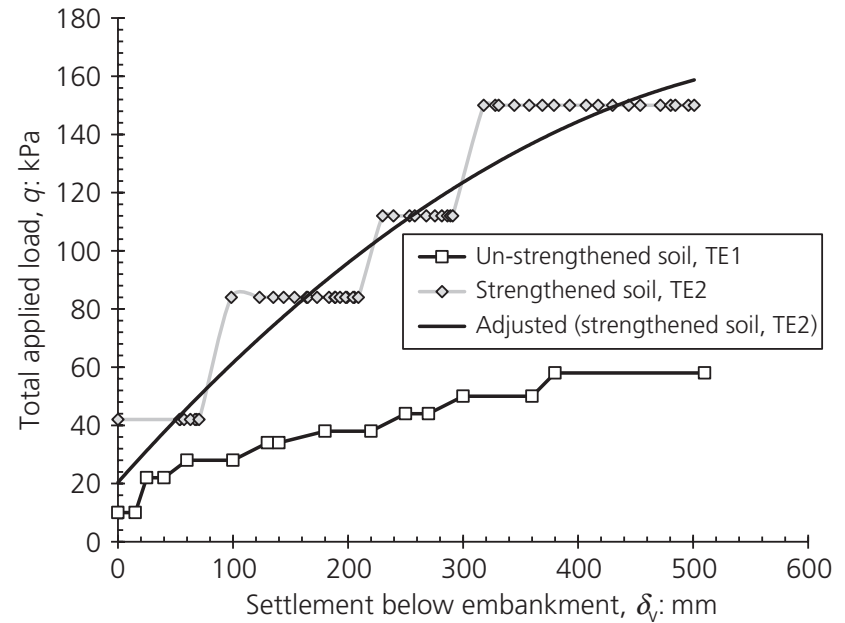

Figure 3. Variations of the settlement below the embankment with the total applied load for TE1 and TE2

\subsection{Horizontal displacement of soft clay foundation}

It is well known that geosynthetic encasement reduces column bulging due to the additional confining stress acting along the column length (e.g. Gniel and Bouazza, 2010; Khabbazian et al., 2010; Murugesan and Rajagopal, 2006; Yoo and Lee, 2012); nevertheless, few field studies comparing the horizontal displacement of a soft foundation with and without granular encased columns are available. In order to assess the effectiveness of the encased columns on the lateral deformation of the foundation soil, the maximum values of the soil horizontal displacement $\left(\delta_{\mathrm{h}, \max }\right)$ measured by inclinometers are compared in Figure 4. It is clearly seen that the geotextile-encased granular columns (TE2) notably reduced the maximum horizontal displacement of the soft clay foundation. For example, when the total applied load was $q=60 \mathrm{kPa}$, the maximum soil

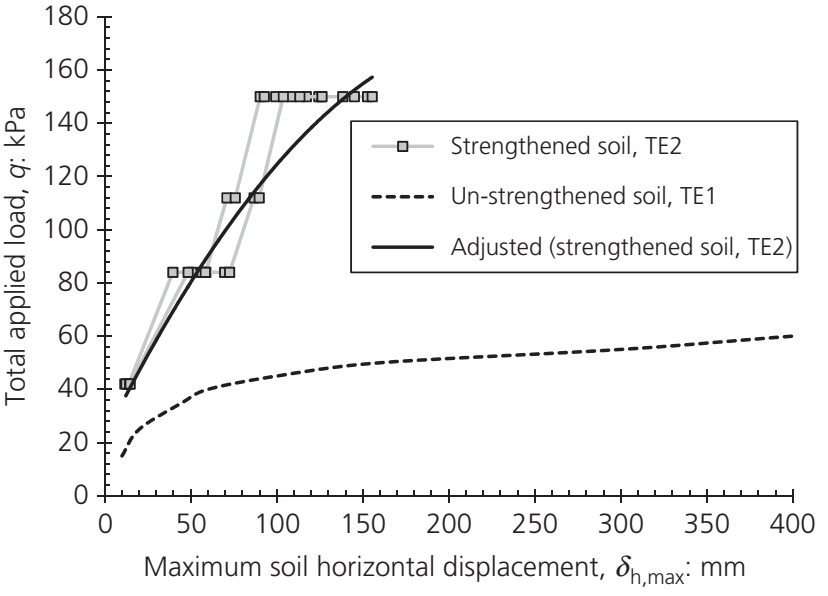

Figure 4. Variations of the maximum soil horizontal displacement with the total applied load for TE1 and TE2

horizontal displacement for TE1 was about $\delta_{\mathrm{h}, \max }=400 \mathrm{~mm}$, over ten times the maximum horizontal displacement measured for TE2.

TE1 showed global failure at a vertical load of $q=60 \mathrm{kPa}$, as reported by Magnani et al. (2010), with a computed safety factor at the end of construction quite close to unity $\left(F_{\mathrm{S}}=1 \cdot 098\right)$. However, the strengthened soft foundation (TE2) did not demonstrate any continuous increase of maximum horizontal displacement at the end of the monitoring period (i.e. measured values did not differ much), while the total applied load was around $2 \cdot 5$ times greater than for TE1, with a computed factor of safety $F_{\mathrm{s}}=1.80$ for TE2 (Hosseinpour, 2015). Therefore, it can be concluded that the use of granular encased columns noticeably enhances embankment performance against the possible global failure of soft foundations. 


\subsection{Relationship of vertical and horizontal deformations}

The maximum horizontal displacement $\left(\delta_{\mathrm{h}, \max }\right)$ of the soft clay may be estimated based on the maximum settlement $\left(\delta_{\mathrm{v}, \max }\right)$ measured below the embankment (Tavenas et al., 1979)

1. $\mathrm{DR}=\frac{\delta_{\mathrm{h}, \text { max }}}{\delta_{\mathrm{v}, \text { max }}}$

Figure 5 shows variations of the ratio of the maximum soil horizontal displacements with the settlements measured below the embankment centreline. It should be noted that the maximum settlement for TE1 does not take place exactly at the embankment centreline, but is displaced towards the slope (Almeida et al., 2011) - a behaviour associated with embankments built with a low safety factor (Almeida et al., 1985). It can be seen that for the strengthened clay foundation (TE2), the horizontal displacement increased linearly with settlement, resulting in a slope (deformations ratio (DR)) varying from $0 \cdot 16$ to $0 \cdot 20$ (measured by two inclinometers), much smaller than the $\mathrm{DR}=0.42$ measured for TE1. Moreover, the differences increased post-construction with $\mathrm{DR}=0.83$ for $\mathrm{TE} 1$ compared with $\mathrm{DR}<0.20$ for $\mathrm{TE} 2$, thus becoming about four times greater for TE1.

DR values for TE2 would probably be even smaller if granular encased columns covered the whole of the embankment basis (Figure 1(b)). Therefore, it can be stated that, unlike conventional embankments, the use of geotextile-encased granular columns resulted in lower values of DR and, in the present case, the DR values were roughly constant during both the construction and the consolidation periods.

\subsection{Excess pore water pressures}

Variations of the excess pore water pressure $(\Delta u)$ measured in the middle of the soft clay under the embankment centreline

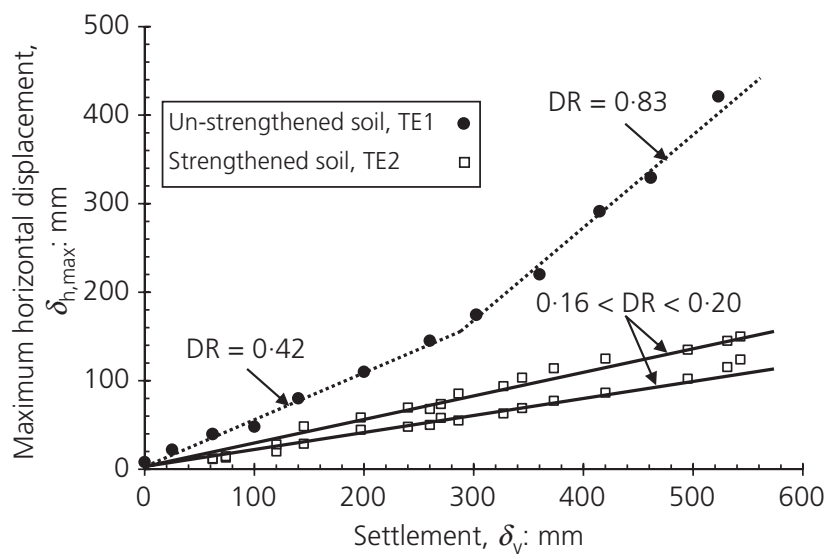

Figure 5. Relationship between settlement and soil horizontal deformation for TE1 and TE2 are plotted against time in Figure 6, together with the total vertical load $(q)$ applied by TE1 and TE2. It should be noted that the values of $q$ for TE1 were corrected for submersion, thus decreasing slightly following the end of construction; however, this correction was not necessary for TE2.

It can be seen that, for both test embankments, the excess pore pressures following load application increased sharply and then dissipated gradually during post-construction; TE1 was provided with PVDs and TE2 with encased granular columns. Unlike the un-strengthened foundation (TE1), the use of geotextile-encased granular columns (TE2) caused the maximum excess pore pressure to reduce significantly, while the total vertical load was 2.5 times greater than the corresponding value for TE1. The reason for this is the stress concentration on the top of the granular encased columns leading to less total vertical load transferred to the soft clay foundation. Considering the dissipation time, it can be observed that the radial drainage offered by the granular columns caused the consolidation time of TE2 to decrease significantly in comparison with TE1. Therefore, $70 \mathrm{~d}$ after the final stage of construction (i.e. 130th day) the values of excess pore pressure were noticeably different for TE1 and TE2, although the latter was subjected to a higher vertical load.

Figure 7 shows the excess pore pressure $(\Delta u)$ normalised with the current load $(q)$ applied by TE1 and TE2. It can be seen that the normalised excess pore pressure obtained from TE1 began at relatively low values in the initial loading stages and increased to a maximum value close to unity with subsequent load application, indicating strict undrained loading conditions during construction. This ratio reduced gradually during postconstruction as consolidation progressed. A different behaviour, however, can be seen during the construction of TE2 as the normalised excess pore pressure increased in loading

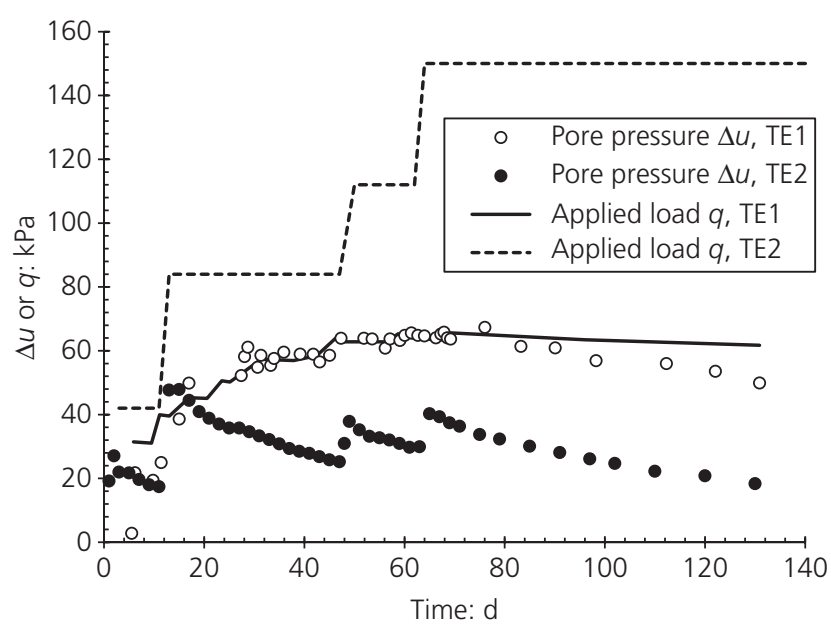

Figure 6. Variations of the excess pore pressure measured in the middle of the soft clay with time for TE1 and TE2 


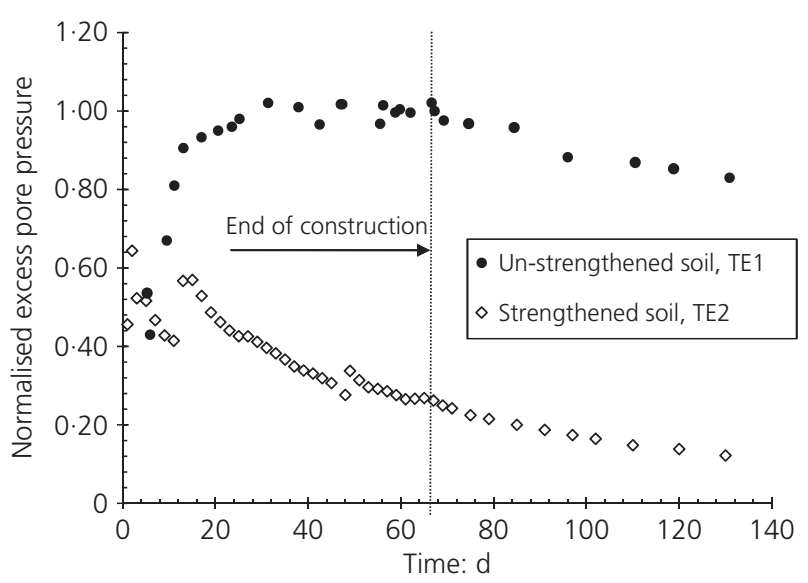

Figure 7. Variations of the normalised excess pore pressure with time for TE1 and TE2

stages 1 and 2, with a maximum value of around $0 \cdot 65$, and then started to reduce gradually in the last two construction stages as well as post-construction. The use of encased granular columns caused the total vertical load transferred into the surrounding soft soil to decrease, leading to a reduction in excess pore pressure during both construction and consolidation intervals compared with TE1. The faster dissipation rate of excess pore pressure for TE2 can be explained by the significant difference in the diameter of the encased granular column compared with the small equivalent diameter of the vertical drain, resulting in a noticeable increase in the degree of consolidation. The average degree of consolidation, for the simplified assumption of purely radial drainage $\left(U_{\mathrm{h}}\right)$ without smear effects for both test embankments, can be obtained by (Barron, 1948)

2. $U_{\mathrm{h}}=1-\mathrm{e}^{-\left(8 T_{\mathrm{h}} / F_{\mathrm{n}}\right)}$

where the time factor for radial drainage is given by

3. $T_{\mathrm{h}}=\frac{c_{\mathrm{h}} t}{d_{\mathrm{e}}^{2}}$

and

4. $F_{\mathrm{n}}=\ln (n)-0.75$ where

5. $n=\frac{d_{\mathrm{e}}}{d_{\mathrm{w}}}$

In Equation $5, d_{\mathrm{w}}$ is equal to the diameter of the granular column for TE2 and $d_{\mathrm{w}}=2(a+b) / \pi$ for TE1 (Hansbo, 1979), considering the rectangular dimensions of the vertical drain to be $a=10 \mathrm{~cm}$, and $b=0.5 \mathrm{~cm}$. Also, the diameter of influence area $\left(d_{\mathrm{e}}\right)$ for the encased granular columns installed in the square mesh and for the vertical drains implemented in the triangular array is $d_{\mathrm{e}}=1.13 S$ and $d_{\mathrm{e}}=1.05 S$, respectively, in which $S$ is the centre-to-centre spacing between the granular columns or vertical drains as mentioned earlier.

The computed degree of radial consolidation at the end of construction for both test embankments is presented in Table 3. It is clearly seen that the large diameter of the granular column (i.e. greater $d_{\mathrm{w}}$ ) significantly accelerates the rate of excess pore pressure dissipation, as the consolidation degree computed at the end of construction of the TE1 was around 3.7 times higher than that for vertical drains. On the other hand, unlike TE1, the use of the geotextile-encased granular columns resulted in faster strength gain in clay during rapid embankment construction on soft clay layers.

\section{Conclusions}

The effectiveness of geotextile-encased granular columns in the field response of a soft clay foundation was assessed by comparing the instrumentation results for two test embankments. The main conclusions are summarised as follows.

A comparison of the settlement measured below the test embankments over strengthened and un-strengthened clay foundations showed that the use of geotextile-encased granular columns reduced the settlement substantially, resulting in a virtual settlement improvement factor of about 5, for equal applied loads.

Similarly to the settlement, the maximum soil horizontal displacement occurring in the soft clay foundation reduced remarkably when geotextile-encased granular columns were used. At the end of the monitoring period, the maximum horizontal displacement of the strengthened soft foundation was

\begin{tabular}{llllllllll}
\hline & $d_{\mathrm{w}}: \mathrm{m}$ & $S: \mathrm{m}$ & $d_{\mathrm{e}}: \mathrm{m}$ & $n$ & $F_{\mathrm{n}}$ & $c_{\mathrm{h}}: \mathrm{m}^{2} / \mathrm{s}$ & $t: \mathrm{d}$ & $T_{\mathrm{h}}$ & $U_{\mathrm{h}}$ \\
\hline TE1 & 0.0668 & 1.3 & 1.37 & 20.51 & 2.27 & $2.1 \times 10^{-8}$ & 60 & 0.0580 & 0.184 \\
TE2 & 0.80 & 2.0 & 2.26 & 2.825 & 0.288 & $3.7 \times 10^{-8}$ & 65 & 0.0406 & 0.676
\end{tabular}

Table 3. Computed degree of consolidation at the end of construction of TE1 (un-strengthened foundation) and TE2 (strengthened foundation) 
about three times less than that of the un-strengthened soft foundation, whereas a total applied load 2.5 times higher was applied. It can be concluded that the use of geosyntheticencased granular columns significantly increases load-carrying capacity and improves embankment stability against a general failure of the soft foundation.

Linear or bilinear relationships $\left(\mathrm{DR}=\delta_{\mathrm{h}, \max } / \delta_{\mathrm{v}, \max }\right)$ were found to correlate the maximum soil horizontal displacement with the maximum settlement for both test embankments. Unlike the un-strengthened soft foundation, the geotextile-encased granular columns caused the DR ratio to increase at a lower rate, and its influence was much more pronounced during post-construction when the DR ratio for un-strengthened foundation was up to around four times that of the strengthened foundation.

A comparison of the excess pore water pressures measured in the middle of the soft clay foundation showed that the ground stabilisation with geotextile-encased granular columns resulted in a significantly lower excess pore pressure following load application. Also, the rate of excess pore pressure dissipation was much faster, as indicated by the computed degree of radial consolidation at the end of the construction of TE2 of $67.6 \%$, around 3.7 times that for the embankment with vertical drains.

\section{REFERENCES}

Ali K, Shahu JT and Sharma KG (2012) Model tests on geosynthetic-reinforced stone columns: a comparative study. Geosynthetics International 19(4): 292-305.

Almeida MSS, Davies MCR and Parry RHG (1985) Centrifuge tests of embankments on strengthened and un-strengthened clay foundations. Géotechnique 35(4): 425-441, http://dx.doi.org/10.1680/geot.1985.35.4.425.

Almeida MSS, Marques MES and Lima BT (2010) Overview of Brazilian construction practice over soft soils. In Symposium New Techniques for Design and Construction in Soft Clays (Almeida MSS (ed.)). Oficina de Textos, Guarujá, Brazil, pp. 205-225.

Almeida MSS, Magnani HO, Dias D and Deotti LOG (2011) Behavior of three test embankments taken to failure on soft clay. Soils and Rocks 34(4): 389-404.

Almeida MSS, Hosseinpour I and Riccio M (2013) Performance of a geosynthetic-encased column (GEC) in soft ground: numerical and analytical studies. Geosynthetics International 20(4): 252-262.

Almeida MSS, Hosseinpour I, Riccio M and Alexiew D (2015) Behavior of geotextile-encased granular columns supporting test embankment on soft deposit. Geotechnical and Geoenvironmental Engineering, ASCE 141(3): 04014116.

Barron RA (1948) Consolidation of fine-grained soil by drain wells. Soil Mechanics and Foundation Division, ASCE 73(6): 811-835.
Bergado DT, Chai J, Alfaro MC and Balasubramanian AS (1994) Improvement Techniques of Soft Ground in Subsiding and Lowland Environment. Balkema, Rotterdam, the Netherlands.

Black JA, Sivakumar V, Madhav MR and Hamill GA (2007) Reinforced stone columns in weak deposits: laboratory model study. Geotechnical and Geoenvironmental Engineering, ASCE 133(9): 1154-1161.

Castro J and Sagaseta C (2013) Influence of elastic strains during plastic deformation of encased stone columns. Geotextiles and Geomembranes 37: 45-53.

Chai J, Miura N and Shen S (2002) Performance of embankments with and without reinforcement on soft subsoil. Canadian Geotechnical Journal 39(4): 838-848.

Gniel J and Bouazza A (2010) Construction of geogrid encased stone columns: a new proposal based on laboratory testing. Geotextiles and Geomembranes $\mathbf{2 8 ( 1 )}$ 108-118.

Greenwood DA (1970) Mechanical improvement of soils below ground surface. In Proceedings of the Ground Engineering Conference. Institution of Civil Engineers, London, UK, pp. 11-22.

Hansbo S (1979) Consolidation of clay by band-shaped prefabricated vertical drains. Ground Engineering 12(5): $16-25$.

Holtz RD (1987) Preloading with prefabricated vertical strip drains. Geotextiles and Geomembranes 6(1-3): 109-131.

Hosseinpour I (2015) Test Embankment on Geotextile-Encased Granular Columns Stabilized Soft Ground. PhD thesis, Graduate School of Engineering (COPPE), Federal University of Rio de Janeiro (UFRJ), Rio de Janeiro, Brazil.

Hosseinpour I, Riccio M and Almeida MSS (2014) Numerical evaluation of a granular column reinforced by geosynthetics using encasement and laminated disks. Geotextiles and Geomembranes 42(4): 363-373.

Hosseinpour I, Almeida MSS and Riccio M (2015) Full-scale load test and finite-element analysis of soft ground improved by geotextile-encased granular columns. Geosynthetics International 22(6): 428-438.

Indraratna B, Balasubramaniam AS and Balachandran S (1992) Performance of test embankment constructed to failure on soft marine clay. Journal of Geotechnical Engineering, ASCE 118(1): 12-33.

Khabbazian M, Kaliakin VN and Meehan CL (2010) Numerical study of the effect of geosynthetic encasement on the behavior of granular columns. Geosynthetics International 17(3): 132-143.

Magnani HO, Almeida MSS and Ehrlich M (2009) Behavior of two reinforced test embankments on soft clay. Geosynthetics International 16(3): 127-138.

Magnani HO, Ehrlich M and Almeida MSS (2010) Embankments over soft clay deposits: contribution of basal reinforcement 
and surface sand layer to stability. Geotechnical and Geoenvironmental Engineering, ASCE 136(1): 260-264.

Mitchell JK and Huber TR (1985) Performance of a stone column foundation. Journal of Geotechnical Engineering, $A S C E$ 111(2): 205-223.

Murugesan S and Rajagopal K (2006) Geosynthetic-encased stone column: numerical evaluation. Geotextiles and Geomembranes 24(6): 349-358.

Raithel M and Kempfert HG (2000) Calculation models for dam foundations with geotextile coated sand column. Proceedings of GeoEngineering, Melbourne, Australia. Technomic Publishing, Lancaster, PA, USA, p. 347 (CD-ROM).
Rowe RK and Leroueil S (2001) Embankments over soft soil and peat. In Geotechnical and Geoenvironmental Engineering Handbook (Rowe RK (ed.)). Kluwer, Kingston, ON, Canada, pp. 463-499.

Rowe RK, Gnanendran CT, Landva AO and Valsangkar AJ (1995) Construction and performance of a full-scale geotextile reinforced test embankment. Canadian Geotechnical Journal 32(3): 512-534.

Tavenas F, Mieussens C and Bourges F (1979) Lateral displacement in clay foundations under embankments. Canadian Geotechnical Journal 16(3): 532-550.

Yoo C and Lee D (2012) Performance of geogrid-encased stone columns in soft ground: full-scale load tests. Geosynthetics International 19(6): 480-490.

\section{HOW CAN YOU CONTRIBUTE?}

To discuss this paper, please email up to 500 words to the editor at journals@ice.org.uk. Your contribution will be forwarded to the author(s) for a reply and, if considered appropriate by the editorial board, it will be published as discussion in a future issue of the journal.

Proceedings journals rely entirely on contributions from the civil engineering profession (and allied disciplines). Information about how to submit your paper online is available at www.icevirtuallibrary.com/page/authors, where you will also find detailed author guidelines. 